\title{
O INRC Marajó como instrumento de registro e de disseminação de informações sobre a cultura marajoara
}

Sheila Fonseca dos Santos*

Rubens da Silva Ferreira**

\section{Resumo}

Este trabalho tem como foco o Inventário Nacional de Referências Culturais (INRC) da Ilha do Marajó, desenvolvido pela representação do Instituto do Patrimônio Histórico e Artístico Nacional (IPHAN) no Pará, com o objeto de analisar tal experiência institucional quanto ao registro e à disseminação de informações sobre os aspectos culturais desse arquipélago. Desse inventariamento produzido entre 2004-2006 por uma equipe interdisciplinar, contratada pelo IPHAN, resultaram os produtos culturais (Inventário, CD-ROM e DVD) que viabilizaram ações de disseminação de informações sobre a cultura marajoara, tais como exposições, palestras, mostra pública de vídeo e de CD-ROM aos educadores dos níveis fundamental e médio de ensino, bem como a entrega de kits às escolas públicas da Ilha e às instituições culturais no Pará e no Brasil, o que se deu como forma de preservar a cultura popular local.

Palavras-chave: Inventário sobre cultura marajoara. Disseminação da informação. Ilha de Marajó, PA, Brasil.

\section{Abstract}

This work have as focus the Inventário Nacional de Referências Culturais (INRC) of the Marajó Island, developed by representation of the Instituto do Patrimônio Histórico e Artístico Nacional (IPHAN) in Pará, with the object to analyze the institucional experience of register and dissemination of information on the cultural aspects of this archipelago. This work went produced in 2004-2006 for a interdisciplinary team, contracted for the IPHAN, had resulted the cultural products (Inventory, CD-ROM and DVD) that possible action of dissemination of information about the culture marajoara, such as expositions, lectures, shows public of video and CD-ROM to the educators of levels basic and average of education, as well as the 
delivery of kits to the public schools of the Island and to the cultural institutions in Pará and Brazil as form to preserve the popular culture.

Key-words: Marajoara culture inventory. Dissemination of information. Marajó Island, PA, Brazil.

\section{Introdução}

No contexto da sociedade contemporânea a informação tem tido papel fundamental, pois se configura como matéria-prima no processo de geração de conhecimento em sua dimensão científica, teológica, filosófica, mítica ou comum, bem como instrumento de transmissão e assimilação da cultura, quer no contexto das sociedades simples e/ou complexas. Todavia, uma análise na literatura especializada em Biblioteconomia e em Ciência da Informação é reveladora de que a academia tem tradicionalmente centrado a atenção nos estudos sobre a informação científica e tecnológica (PINHEIRO; LOUREIRO, 1995; ALMEIDA, 2006; ARRAYA; VIDOTTI, 2009), em detrimento àquela produzida pelas camadas populares. Nesta perspectiva, o presente trabalho consiste em uma análise da experiência do Instituto do Patrimônio Histórico e Artístico Nacional (IPHAN), em sua representação regional no estado do Pará, no que diz respeito ao trabalho de inventariamento e disseminação de informações sobre o patrimônio cultural da llha do Marajó, Pará.

O Inventário Nacional de Referências Culturais (INRC) (1) da llha de Marajó consistiu num levantamento sistemático sobre os bens culturais de natureza material e imaterial desse arquipélago paraense, cujos trabalhos foram realizados no período 2004-2006 por uma equipe interdisciplinar contratada pelo IPHAN. Esta ação se deu na conjuntura do Programa Nacional do Patrimônio Imaterial, instituído na gestão do então presidente Fernando Henrique Cardoso através do Decreto ํㅜ 3.551/2000 (BRASIL, 2006). Por meio dessa política, que está em consonância com as discussões internacionais promovidas pela UNESCO para a salvaguarda da cultura tradicional e popular e do patrimônio imaterial (CONVENÇÃO..., 2004, p. 371-390; RECOMENDAÇÕES..., 2004, p. 293-301), ações de inventariamento, registro e disseminação desses saberes têm sido implementadas em todo o Brasil. Porém, 
mais do que focar a preservação, tais ações são orientadas para viabilizar o acesso democrático da sociedade mais ampla aos saberes associados às diferentes formas de expressão da cultura e das tradições populares brasileiras.

Do ponto de vista metodológico, este trabalho é fruto de uma pesquisa documental produzida a partir do Manual de Aplicação do INRC e da versão impressa do INRC Marajó (composto pelo Inventário propriamente dito, em dois volumes, e pelo Relatório de Atividades). Os autores deste trabalho também participaram direta e/ou indiretamente dessa experiência, uma vez que possuíam vínculo com o IPHAN (2). Com efeito, na produção de evidências também foram ouvidas pessoas envolvidas no projeto, qual seja uma integrante da equipe de pesquisa e uma técnica do IPHAN no Pará. Relatórios de viagem da fase de lançamento desse Inventário no Marajó puderam ser consultados, bem como documentação fotográfica, o que permitiu compreender parte do background da disseminação de informações sobre os bens culturais da llha de Marajó. Ademais, ao considerar-se que o levantamento bibliográfico consiste em atividade seminal para qualquer empreendimento acadêmico (ECO, 1996), fontes diversas como trabalhos apresentados em eventos técnico-científicos, livros, capítulos de livro e artigos de periódicos são tomados para subsidiar a discussão.

Assim, vistas estas considerações iniciais, o que se segue diz respeito à exposição do quadro teórico necessário ao entendimento conceitual do trabalho. Posteriormente, a experiência de registro e de disseminação de informações que resultaram do INRC sobre a cultura marajoara é tomada para análise. E, ao fim, são apresentadas as considerações finais, nas quais se destaca a importância da experiência do IPHAN quanto à elaboração de produtos culturais para além do segmento acadêmico, atingindo principalmente ilhéus e ilhoas do arquipélago do Marajó.

\section{Perspectivas teóricas}

Em direção a uma abordagem da experiência do IPHAN sob a ótica da Ciência da Informação, ou seja, de uma Ciência Social Aplicada de natureza interdisciplinar que se dedica ao estudo dos processos sociais de produção, organização, armazenamento, recuperação, disseminação e uso da informação (BRAGA, 1995; 
ANDRADE, OLIVEIRA, 2005), há que se discutir dois conceitos: informação e disseminação da informação. Por conseguinte, de acordo com Zeman (1970, p. 156), a palavra informação deriva do termo latino informare, que quer dizer "dar forma", "formar", "representar", "instruir", "criar" uma ideia ou noção, o que o leva a explicar que "[...] a informação é também a classificação de símbolos e de suas ligações em uma relação, seja a organização dos órgãos e funções de um ser vivo ou a organização de um sistema social qualquer ou de qualquer outra comunidade em geral [...]". Neste contexto, ela está relacionada ao que é organizado, ao que está em ordem, inclusive os estímulos do meio que ao causar uma impressão no indivíduo são cognitivamente processados para a produção de sentido sobre o mundo exterior em toda sua complexidade.

Conforme Capurro e Hjorland (2007, p.160):

\begin{abstract}
A noção de informação tem sido usada para caracterizar uma medida de organização física (ou sua diminuição na entropia), um padrão de comunicação entre fonte e receptor, uma forma de controle e feedback, a probabilidade de uma mensagem ser transmitida por um canal de comunicação, o conteúdo de um estado cognitivo, o significado de uma forma lingüística ou redução de uma incerteza.
\end{abstract}

Destarte, para esses autores os entendimentos sobre o termo informação provêm de diversas áreas do conhecimento, tais como a Física, a Comunicação e a Psicologia, entre outras, e, ainda, ressaltam que não há uma ideia comum do ponto de vista conceitual, o que se configura um problema para a Ciência da Informação. E tal como conclui Stonier (1990 apud CAPURRO; HJORLAND, 2007, p. 165), a informação não depende da assimilação, pois ela existe mesmo que não seja apreendida, destacando também a necessidade de diferenciar informação e significado. Isto é, para ele a informação somente terá significado se e somente se for processada (assimilada) por um receptor.

Ainda sobre a informação, Capurro e Hjorland (2007, p. 162) destacam que a concepção moderna desse termo é "desumanizada". Quer dizer, "[...] não apenas seres vivos [além dos humanos], mas também todos os tipos de sistema são tidos como produtores, processadores e compartilhadores de informação". Esse 
entendimento baseia-se no significativo aumento da quantidade de informação gerada pela sociedade por meio dos recursos das Novas Tecnologias de Informação e Comunicação (NTIC), as quais têm potencializado as possibilidades de disseminação de informações na sociedade contemporânea.

Disseminação da informação, por sua vez, constitui-se num conceito basilar para a Biblioteconomia, inclusive para a Arquivologia, para a Documentação e para a Museologia, isto porque o pressuposto básico dessas ciências/disciplinas não reside na ideia de formar acervos e/ou coleções pura e simplesmente para fins de estoque ou guarda como o cidadão comum ou o segmento científico podem ser levados a pensar; mas para viabilizar o acesso aos conteúdos (informações) tecnicamente trabalhados nos contexto das bibliotecas, dos arquivos, dos centros de documentação e dos museus.

Assim, segundo Oliveira (2000, p. 2-3), a palavra disseminar pode ser entendida como "difundir, espalhar, semear [...]. A disseminação da informação [...] é antiga e considerada por muitos autores como o ato de levar a informação ao usuário por meio de [determinados] canais de comunicação", sejam estes formais (livros, artigos de periódicos etc.) ou informais (congressos, conversas, e-mails, reuniões, telefonemas, etc.). Há que se perceber nesta direção que a disseminação da informação possui um caráter democrático sobre o qual repousa o exercício do direito à informação, o que para Valle (2005) é em si um direito coletivo, precipuamente quando o que se quer disseminar envolve o produto e os efeitos das políticas estatais que não representam ameaça à soberania nacional, ou seja, constitui informação de natureza essencialmente pública.

Logo, disseminar a informação significa comunicá-la de maneira ampla, o que se configura também como uma das atividades-fim do IPHAN (IPHAN, [2009]), haja vista que o volume de informações produzido sobre os bens culturais de natureza material ou imaterial tem caráter público, devendo por isso ser difundido no sentido de sensibilizar a população para a preservação do patrimônio cultural e, por extensão, da memória nacional. E tido como uma autarquia federal, esse órgão está 
condicionado à Norma Constitucional em seu Artigo 216, § 20, segundo a qual "cabem à administração pública, na forma da lei, a gestão da documental governamental e as providências para franquear sua consulta a quantos dela necessitarem" (BRASIL, 2009, p. 141). Todavia, como bem coloca Valle (2005), não se trata apenas de "franquear a consulta", senão também o dever do Poder Público em coletar, produzir e disseminar informações, sejam estas voltadas para necessidades diretivas institucionais ou para a coletividade.

E como será mostrado a seguir, as ações de inventariamento do patrimônio cultural imaterial (3) implementadas em âmbito nacional pelo IPHAN - no que se inclui o INRC Marajó - envolvem tanto a produção e a disseminação de informações quanto a garantia do acesso público aos produtos dessas iniciativas. De todo modo, como este trabalho revela, há que se ampliar a difusão dos conhecimentos referentes aos bens culturais no Brasil. Pois, ao se pensar sobre a diversidade cultural do país, os inventários do IPHAN ainda possuem pouca visibilidade nacional, o que de certa forma pode vir a ser atenuado com o uso das NTIC, a exemplo da Grande Rede Mundial de Computadores.

\section{INRC Marajó como instrumento de registro e disseminação de informações sobre a cultura marajoara}

De acordo com Davenport (1998), a maior parte das informações existentes no mundo permanece armazenada nas meninges dos homens, o que as tornam vulneráveis ao esquecimento, haja vista não estarem registradas em algum suporte material. Uma evidência nesta direção se dá no contexto da cultura popular, na qual a tradição oral e a observação se impõem à transmissão dos saberes sobre as práticas cotidianas dos sujeitos, a exemplo da produção de cerâmica, da cestaria, da carpintaria, das ladainhas e das orações, da tradição culinária, das crenças no sobrenatural (4), das lendas, das memórias sobre o passado vivido e/ou ouvido; enfim, de um rol de outros elementos que marcam o dia a dia dos indivíduos e das comunidades. 
Com efeito, o INRC é em si um instrumento voltado para a documentação (o registro (5)) desses bens culturais, fixando essas informações em um banco dados para posterior recuperação e disseminação. De um modo geral, o INRC permite: (1) o conhecimento sobre os saberes e as práticas culturais populares, através de uma descrição minuciosa e sistemática; (2) a patrimonialização dos bens culturais, convertendo-os em objeto de proteção federal ao declará-los patrimônio cultural imaterial do Brasil; e, (3) a gestão dos bens culturais inventariados, o que implica o acompanhamento, a discussão e elaboração de ações de salvaguarda diante da iminência de desaparecimento no tempo e no espaço, assegurando continuidade histórica dos mesmos.

Desse modo, em 2004 a representação do IPHAN no Pará iniciou o INRC Marajó em 12 municípios, a saber: Afuá, Anajás, Breves, Cachoeira do Arari, Chaves, Curralinho, Muaná, Ponta de Pedras, Salvaterra, Santa Cruz do Arari, São Sebastião da Boa Vista e Soure (6) (IPHAN, 2006). Tal como orienta o Manual de Aplicação do INRC (IPHAN, 2000), a equipe envolvida na coleta das informações foi composta por uma equipe interdisciplinar formada por geógrafos, antropólogo, turismólogo, musicólogo e programador visual. E como declara uma das participantes da equipe, a realização do trabalho de campo em uma ilha com as proporções e as particularidades geográficas e naturais do Marajó impôs o desenho de uma estratégia de pesquisa que demandou apoio das prefeituras, pois:

Os pesquisadores não conheciam o Marajó e a grande extensão da ilha dificultou de certa forma o desenvolvimento das atividades de pesquisa. Para solucionar tais problemas, a equipe solicitou o apoio das prefeituras no sentido de que disponibilizassem um servidor para orientá-los de forma a localizar os municípios, mas nem sempre eram atendidos. Buscou-se também parceria com as rádios para melhor divulgação do trabalho [...]. Era a primeira vez que os pesquisadores estavam tendo contato com a metodologia do INRC pelo fato de terem sido contratados especificamente para a elaboração do Inventário do Marajó [...]. Foram realizadas entrevistas com os atores culturais ou mestres da cultura [benzedeiras, pescadores, músicos, artesãos, pajés, etc.], essas entrevistas duravam em média uma hora e meia. No final da pesquisa o ator cultural recebia um panfleto explicativo sobre o trabalho realizado pelos profissionais [...]. A equipe observou que geralmente $o$ ator cultural não reconhece $o$ valor e a importância do saber que possui, pois os bens culturais são vistos como práticas comuns e rotineiras. Diante disso, os profissionais tinham que ter todo um 
cuidado e sensibilidade para que não fossem mal interpretados pelos atores culturais, uma vez que os trabalhos de pesquisa visavam valorizar ainda mais a cultura produzida pelo povo marajoara [...]. [Posteriormente] $\mathrm{O}$ material obtido através das pesquisas foi sistematizado para divulgação. (Entrevista concedida aos autores por Karla Oliveira, turismóloga, integrante da equipe de pesquisa do INRC Marajó, em 18 jun. 2009).

Nesse discurso chama atenção o fato dos atores culturais contatados pela equipe de pesquisa não reconhecerem a importância de suas práticas culturais, notadamente pelo caráter prático e rotineiro com o qual acionam o repertório informacional necessário à realização dessas práticas, o que justifica a importância do INRC Marajó em direção à valorização da cultura marajoara.

Do ponto de vista da Biblioteconomia e da Ciência da Informação, o INRC Marajó pode ser entendido como uma base de dados híbrida, uma vez que reúne informações sobre os bens culturais imateriais, referências de material bibliográfico sobre a llha, conteúdos audiovisuais, textuais e factuais. A coleta das informações se dá por meio de fichas específicas, constituídas por uma diversidade de campos (7), que permitem a descrição dos bens culturais inventariados. Assim, neste sentido, faz-se necessário apresentar cada ficha em particular e os respectivos campos que as constituem, a fim de evidenciar os elementos que formam o conjunto das informações a serem disseminadas para a sociedade, conforme consulta ao Manual de Aplicação do INRC (IPHAN, 2000):

a) ficha de identificação de sítio: o objetivo desta ficha consiste em reunir informações sobre a localização geográfica do bem inventariado; fotos; referências culturais (resumo dos bens inventariados na área); descrição do sítio; formação histórica; perfil socioeconômico; plantas, mapas e croquis; legislação (instrumento de proteção e planejamento ambiental e patrimonial); avaliação e perspectivas (problemas, possibilidades e recomendações); documentos anexados (cadastrados na bibliografia); técnicos responsáveis pela coleta das informações;

b) ficha de Identificação de localidade: o objetivo desta ficha consiste em coletar informações contextuais sobre a área na qual está sendo realizado o inventariamento do bem cultural, como o nome da localidade e/ou do município; fotografias; referências culturais (quantidade e características dos bens culturais identificados na localidade); descrição das áreas (população, patrimônio ambiental, edificações importantes); formação histórica; plantas mapas e croquis; legislação 
(instrumento de proteção ambiental, patrimonial e de planejamento); avaliação e perspectivas (problemas e possibilidades); documentos anexados; identificação da ficha (equipe de pesquisa, supervisor, redator, responsável pela coleta das informações);

c) ficha para a bibliografia: esta ficha tem como objetivo reunir a descrição da documentação bibliográfica relacionada à área e ao bem cultural inventariados. $\mathrm{A}$ ficha orienta que sejam obedecidas as normas da ABNT. Assim, esta ficha constituise de dados sobre os seguintes elementos: livros; publicações seriadas e não seriadas; pequenos impressos (folders; cartazes, etc.); textos inéditos, técnicos responsáveis, relatórios técnicos e manuscritos;

d) ficha de registros audiovisuais: esta ficha tem como finalidade reunir informações sobre os registros audiovisuais referentes aos bens culturais inventariados. A referida ficha é composta por fotografias e artes visuais; vídeo; gravação sonora; CD-ROM e outros registros digitais; dados sobre os técnicos responsáveis pela coleta das informações;

e) ficha de bens culturais inventariados: a finalidade desta ficha é de reunir informações sobre as características dos bens culturais e classificá-los de acordo com as categorias definidas pela metodologia do INRC (celebrações, edificações, formas de expressão, lugar, ofícios e modos de fazer). Para o preenchimento desta ficha têm-se os seguintes campos: denominação (nome como o bem é conhecido); tipo (categoria do bem); condição atual (vigente, memória ou ruína); ocorrência (época e lugar); descrição (síntese das principais características e etapas se for o caso, público envolvido); registros (título); contatos (pessoa ou instituição que poderá fornecer informações sobre o bem);

f) ficha de contatos: esta ficha tem como objetivo registrar informações sobre pessoas e instituições que possam informar a respeito dos bens culturais existentes no sítio inventariado. Nesta ficha existem os seguintes campos sobre os contatos: nome (pessoa ou instituição); como é conhecido (a); data de nascimento ou fundação; endereço; telefone; fax; e-mail; ocupação (atividade principal); local de nascimento; tempo de residência na cidade/localidade; bem cultural; observação (de que forma o entrevistado participa da atividade ou teve informações sobre o bem cultural). 
Em síntese, é este conjunto de informações que compõem o Inventário. E como se pode observar, este instrumento de coleta de dados fornece toda a base empírica e documental necessária à identificação dos bens culturais, uma vez que a ideia do inventário é que ele reúna um número suficiente de informações capazes de permitir que bens culturais perdidos no passado possam ser reavivados, ou, em alguns casos, apenas para que se tenha algum registro da existência do mesmo enquanto memória. Todavia, num plano mais amplo, tais informações destinam-se, também e principalmente, à divulgação dos bens culturais para a sociedade brasileira, notadamente no sentido da difusão ampla do patrimônio cultural brasileiro.

Após o levantamento e o registro sistemático das informações sobre os bens culturais da llha do Marajó, o IPHAN e a equipe de pesquisa voltaram-se à elaboração dos produtos para a disseminação da cultura marajoara. Dentre esses produtos tem-se a versão impressa do INRC Marajó em três volumes. O primeiro volume reúne informações históricas sobre o processo de ocupação da llha, assim como as fichas de identificação de sítio e de identificação dos municípios inventariados devidamente preenchidas, e, ainda, os anexos (bibliografia referente à cultura marajoara e os dados dos registros audiovisuais dos municípios). No segundo volume são apresentados os bens culturais inventariados no município de Cachoeira do Arari, Salvaterra, Soure, Muaná, Breves, Ponta de Pedras, Santa Cruz do Arari, Chaves, Afuá, São Sebastião da Boa Vista, Anajás, Curralinho. Esse volume também contém as fichas correspondentes a aproximadamente 500 contatos realizados pelos pesquisadores na Ilha. E, por fim, um terceiro volume corresponde ao Relatório de Atividades da equipe de pesquisa, onde podem ser encontrados registros sobre as dificuldades e a condução da coleta de informações.

A própria base de dados do INRC Marajó em versão digital - especificamente desenvolvida em software Access - também é um produto cultural. Entretanto, em termos de disseminação e acesso existem restrições, pois há a responsabilidade institucional de preservar a integridade do conjunto das informações armazenadas nessa base. Por outro lado, importa mencionar o esforço do IPHAN na disponibilização das bases de dados dos bens culturais de natureza imaterial que já foram registrados como patrimônio cultural do Brasil (8). Neste caso, o projeto prevê a disponibilização das bases de dados desses bens no Portal IPHAN 
(http://portal.iphan.gov.br), sendo que até o momento há um protótipo disponível apenas na Intranet, portanto, indisponível para o cidadão. E ao que tudo indica, o acesso a esse banco de dados ainda está longe de se tornar uma realidade em direção à democratização das informações sobre esses bens culturais na perspectiva do ciberespaço.

Por outro lado, experiências mais bem-sucedidas se deram a partir do lançamento de um CD-ROM e de um DVD que integram o chamado kit Marajó, produzido em uma tiragem de 1.000 exemplares e acondicionados em estojos de miriti - como se vê na Figura 1 - para distribuição às escolas da llha do Marajó e às instituições culturais no Pará e no Brasil. Efetivamente a disseminação desses produtos culturais ocorreu a partir de 10 de outubro e se estendeu até dezembro de 2007, com lançamento na sede do IPHAN no Pará. Numa concepção dinâmica, o lançamento desses produtos envolveu a realização de uma exposição intitulada "Marajó: conhecer para preservar", na qual foram reunidos banners sobre as celebrações, as formas de expressão, os ofícios e modos de fazer, as edificações e os lugares relacionados à cultura marajoara, conforme as informações fornecidas pelos atores culturais à equipe de pesquisa. Objetos como uma cela utilizada pelos vaqueiros marajoaras, boi-bumbá, cestas diversas, cerâmica, casquinho (9) e uma máquina de processar açaí em madeira, bem como instalações também integraram a exposição. Sobre esta última merece destaque a adaptação de um espaço dedicado aos ritos e rituais da pajelança cabocla, um sistema de crença e de cura que sintetiza elementos da cultura indígena, portuguesa e africana (MAUÉS, 1990, 1995) cada vez menos comum na llha do Marajó. Uma parte desta instalação pode ser vista na Figura 2. 


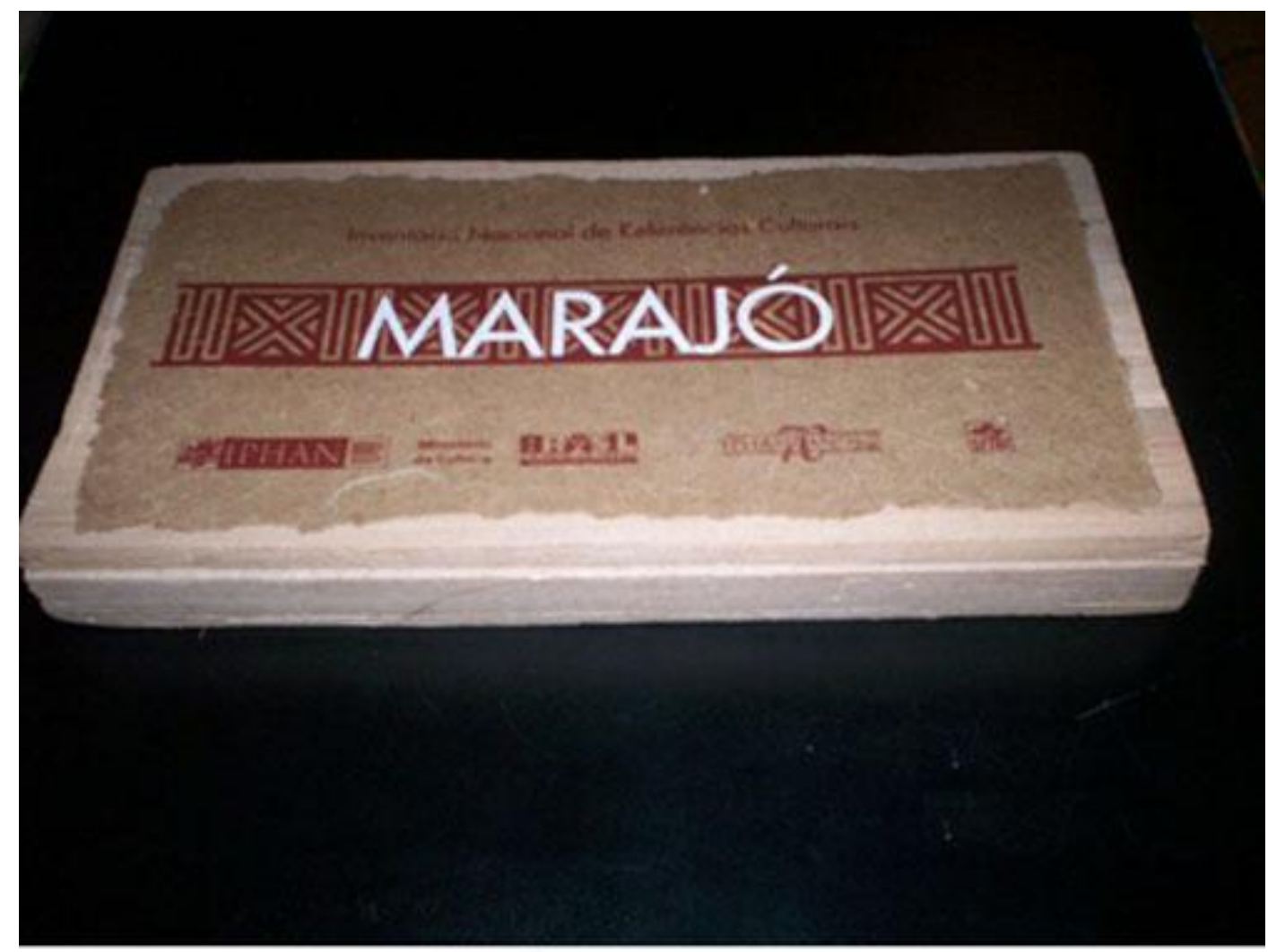

FIGURA 1 - O chamado kit Marajó é composto de um DVD e de um CD-ROM. Na foto tem-se uma mostra do estojo confeccionado em miriti (Mauritia flexuosa), com rótulo de papel reciclado. Foto: Rubens Ferreira, 2007.

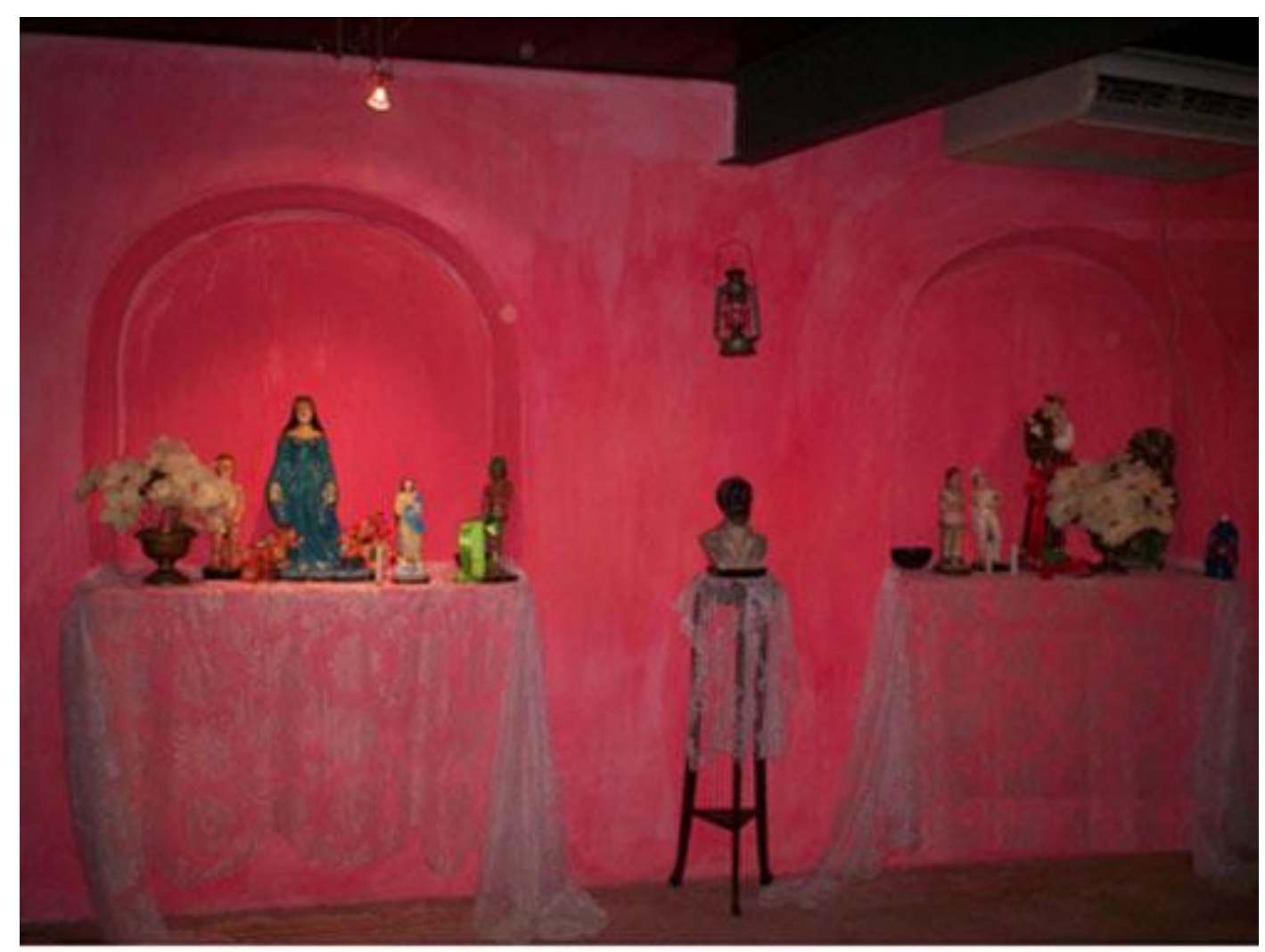

FIGURA 2 - Vista parcial da instalaçăo sobre pajelança marajoara. Foto: Rubens Ferreira, 2007. 
Posterior à exposição, o IPHAN promoveu três dias de palestras sobre a cultura marajoara. Nesta direção, os autores que participaram do INRC Marajó escrevendo papers incorporados ao CD-ROM foram convidados para a comunicação oral desses trabalhos, os quais tratam de temas como encantaria, patrimônio arqueológico, pajelança cabocla, oralidade e história da ocupação da llha. No entanto, talvez por falta de uma divulgação maior ou, ainda, pelo espaço utilizado para o evento (10), essa programação contou com uma participação mínima de pessoas, sendo que o público era constituído no mais das vezes pelos próprios técnicos, estagiários e bolsistas do IPHAN.

Outra atividade de disseminação das informações reunidas no INRC Marajó consistiu no lançamento dos produtos culturais, e em uma exposição itinerante nos municípios visitados pela equipe de pesquisa quando da realização do Inventário. Tal atividade envolveu a participação dos pesquisadores e de técnicos do IPHAN. Os deslocamentos se deram pela via fluvial e a logística das atividades de disseminação foi facilitada pelos contatos que os pesquisadores possuíam de viagens anteriores. Em geral, os trabalhos em cada município envolviam: (1) contato com as autoridades locais (prefeitos e secretários municipais de cultura e/ou educação para auxílio nos trabalhos da equipe no município); (2) distribuição dos convites aos informantes que participaram na etapa do inventariamento, tal como mostra o registrado na Figura 3, abaixo; (3) divulgação do lançamento do kit nas rádios comunitárias, a fim de mobilizar a população local para assistir a exibição pública do DVD e visitar a exposição itinerante; (4) contato com a direção das escolas públicas para agendamento e mobilização dos educadores para a amostra do CD-ROM, a fim de divulgar os conteúdos desse produto (textos, imagens, vídeos) para aproveitamento em disciplinas como História, Geografia, Língua Portuguesa, Literatura e Biologia, por exemplo. 


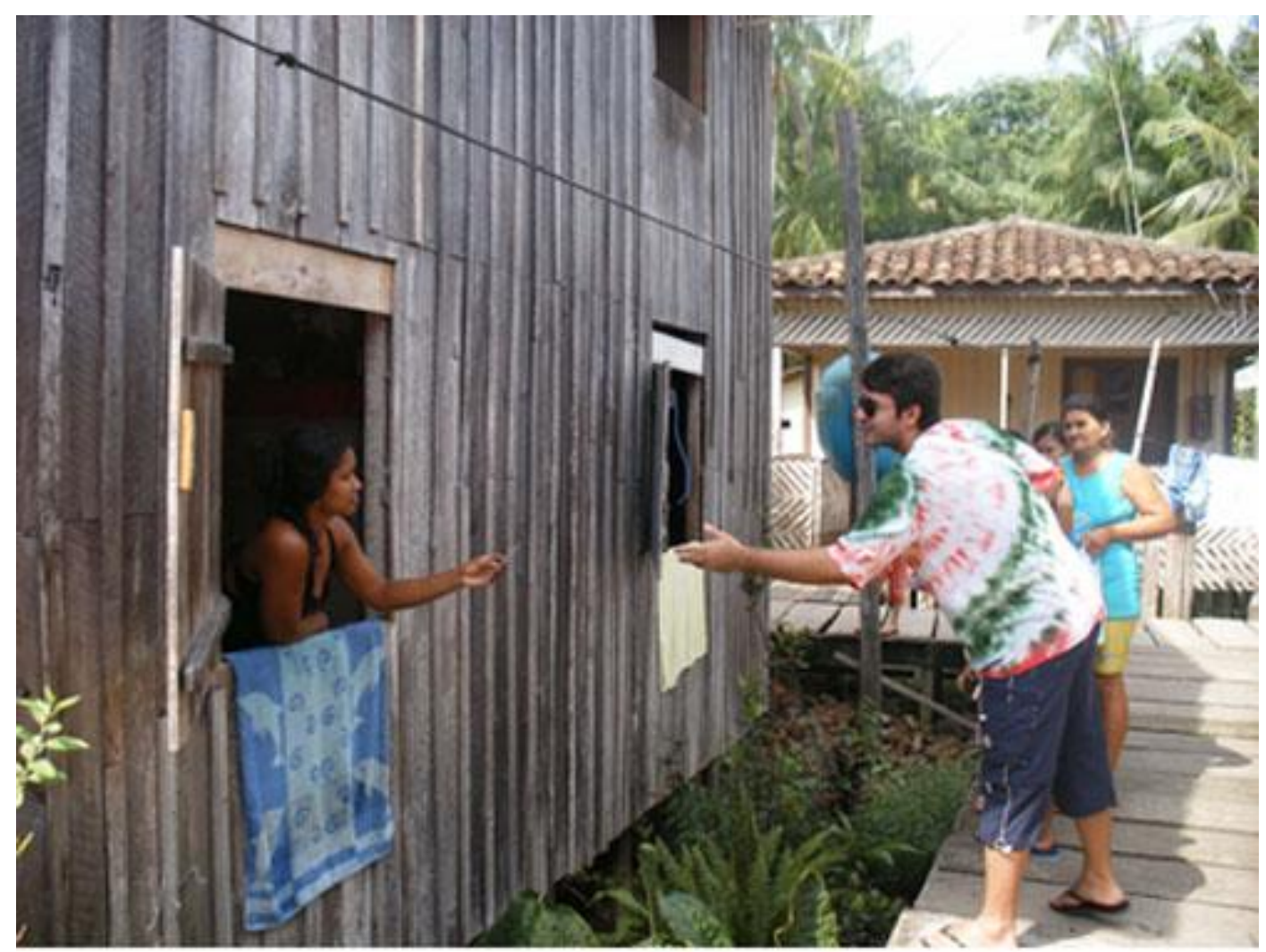

FIGURA 3 - Rubens Ferreira, membro da equipe de divulgaçăo entregando convite para o lançamento do INRC Marajó no município de Muaná. Foto: Karla Oliveira, 2007.

A mobilização nas rádios, os contatos com as autoridades locais e com os informantes ocorriam geralmente às sextas-feiras. $O$ encontro com os educadores $e$ a entrega dos kits às escolas ocorria sempre nas manhãs de sábado. Em alguns momentos a equipe lidava com a resistência dos professores que não estavam dispostos a participar da mostra do CD-ROM em dia normalmente dedicado ao descanso. Dessa forma, essa atividade nem sempre contava com uma presença expressiva de educadores; todavia, os que se faziam presentes demonstravam interesse e aceitação ao material informativo. Um registro fotográfico dessa atividade pode ser visto na Figura 4. A exposição e a apresentação pública do DVD eram realizadas sempre ao final das tardes de sábado. Antes da apresentação do vídeo a equipe explicava à plateia o que era o IPHAN e no que consistia o INRC Marajó. Em Salvaterra a disseminação das informações ocorreu na orla e contou com a participação de um grupo folclórico, que aparece representado na Figura 5, bem como de uma roda de carimbó (11) (FERREIRA, 2007a). Em Muaná, a exibição do vídeo foi realizada no barracão da Igreja Católica local. Era interessante observar a 
reação centrada dos participantes, ou as gargalhadas quando identificavam algum ator cultural com o qual tinham algum contato, ou, ainda, quando os informantes viam a si mesmos no vídeo (FERREIRA, 2007b). Ao final eram realizadas muitas perguntas ou, ainda, reclamações quando os bens culturais de um município apareciam de forma mais destacada que outros.

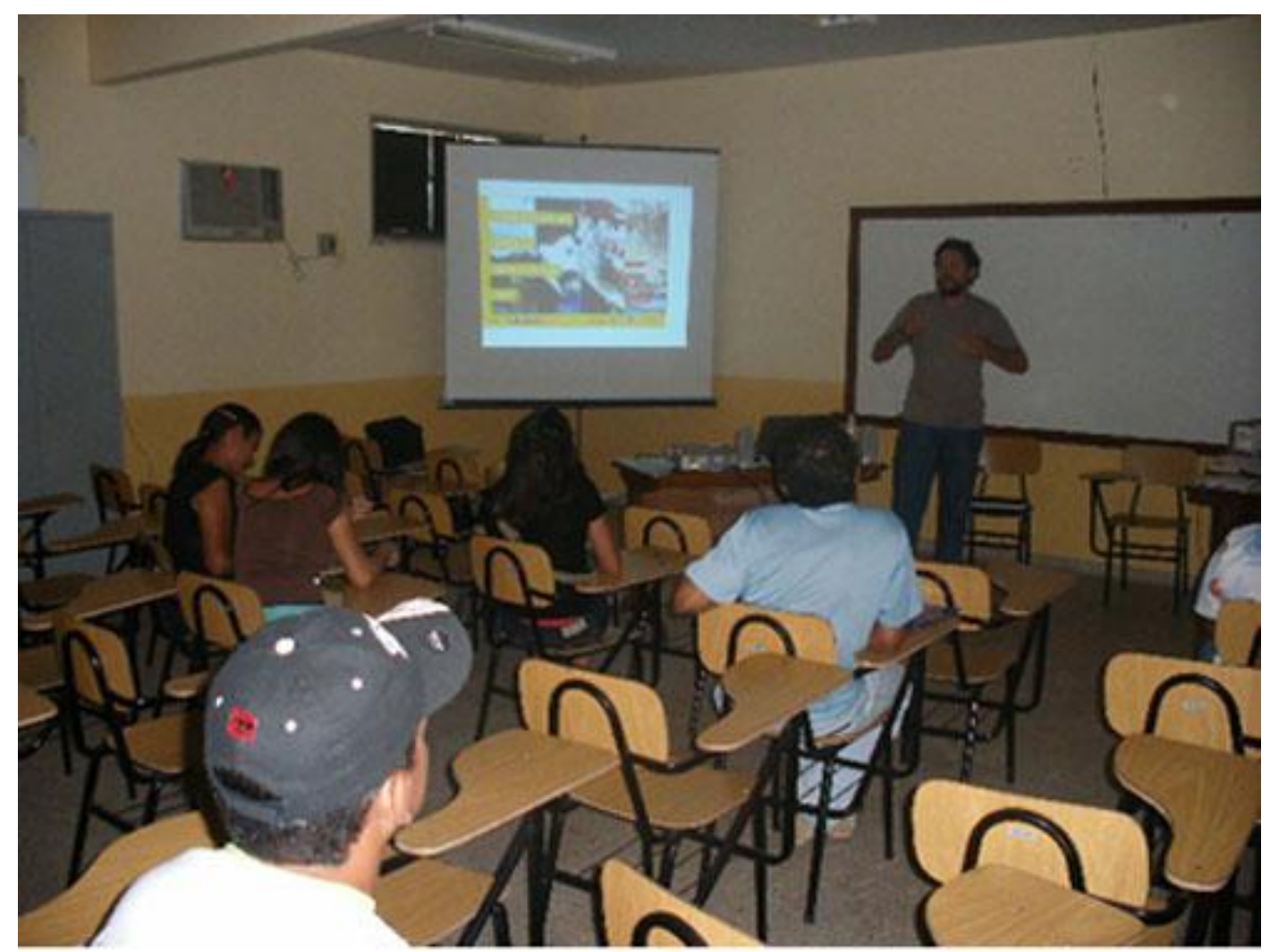

FIGURA 4 - Edgar Chagas Júnior, pesquisador do INRC Marajó orientando professores de Salvaterra sobre a forma de navegação no CD-ROM. Foto: Rubens Ferreira, 2007. 


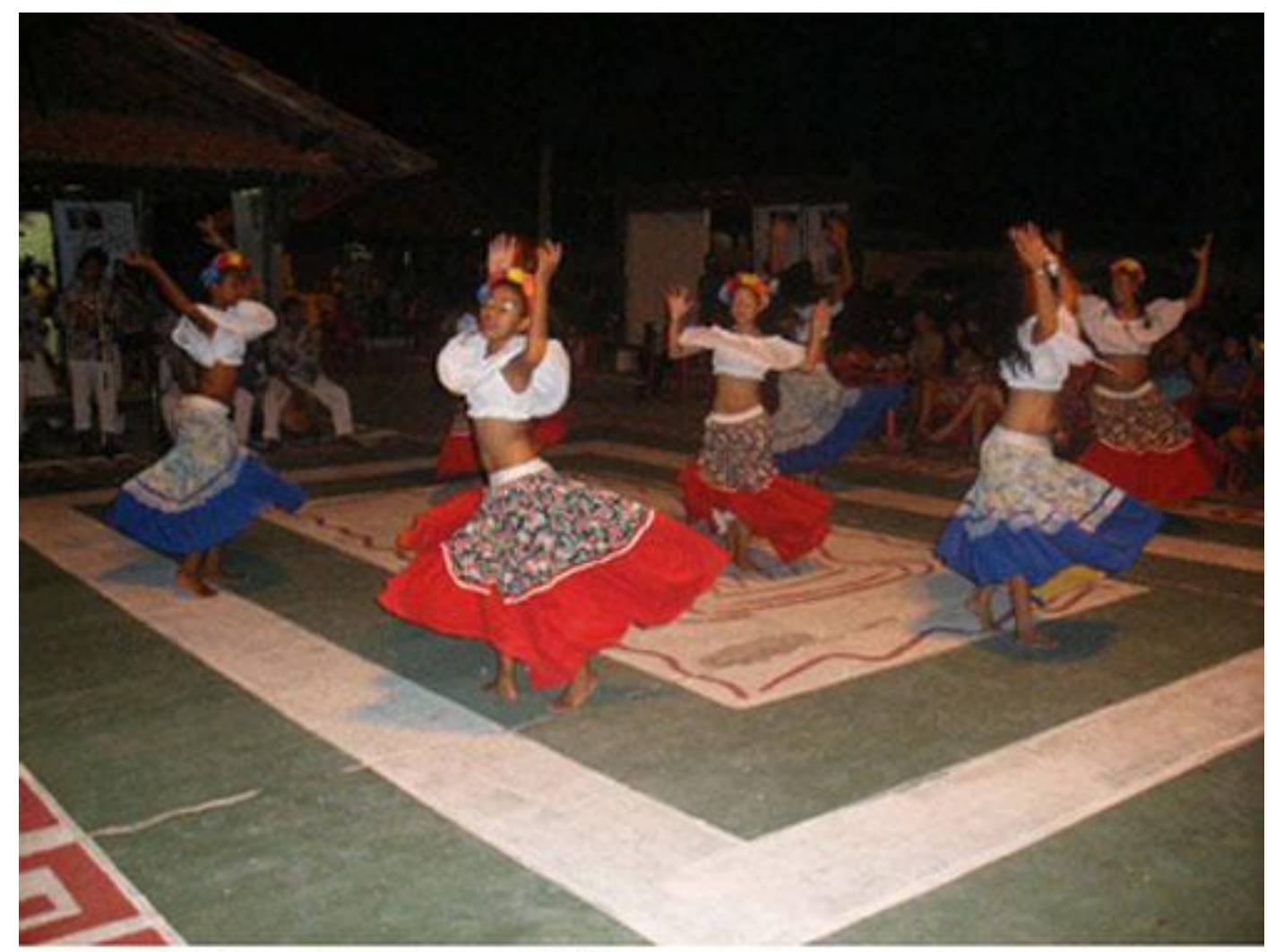

FIGURA 5 - Dançarinas de grupo folclórico em performance no lançamento do INRC Marajó em Salvaterra. Foto: Rubens Ferreira, 2007.

Um descolamento permeado por dificuldades se deu no município de Ponta de Pedras. Ao chegar nessa cidade que consiste num dos pólos turísticos do Marajó, a Secretaria de Educação estava completamente envolvida com as ações do Projeto Rondon. Por conta disso, o trabalho desenvolvido pala equipe não conseguiu gerar visibilidade para o INRC Marajó, diferentemente do que ocorreu em Salvaterra e Muaná, por exemplo. Os educadores das escolas públicas de Ponta de Pedras estavam participando das oficinas de reciclagem do Projeto Rondon, manifestando por isso pouco interesse para com os produtos culturais que foram desenvolvidos para fortalecer a identidade e valorizar a cultura local (FERREIRA, 2007c). Até mesmo a entrega dos kits foi agendada pela Secretária de Educação, Sra. Clevelane, para ocorrer no dia do encerramento do Projeto Rondon, quando professores preparavam a despedida para os integrantes daquela equipe. Ademais, a exibição do DVD ocorreu em uma praça pública onde era realizada uma festa de aparelhagem. Notadamente o público preferia que o DVD terminasse logo para que pudessem voltar a beber e a dançar. Dessa maneira, parece que nesse município o INRC Marajó não obteve boa aceitação. 
Parte da equipe de pesquisa do INRC e outros técnicos do IPHAN participaram das atividades de disseminação da informação nos municípios de Breves, Cachoeira do Arari, Chaves, Curralinho, São Sebastião da Boa Vista (ver Figura 6) e Soure, ainda em 2007. Contudo, Afuá, Anajás e Santa Cruz do Arari não puderam ser visitadas dado o encerramento financeiro do exercício de 2007, de modo que somente em 2008 a entrega dos kits, a mostra de vídeo e exposição itinerante seriam retomadas, o que de fato não ocorreu. De todo modo, tal como informou a técnica Byanca Moraes (12), historiadora, a representação do IPHAN no Pará tem a intenção de retomar as atividades de disseminação das informações do INRC Marajó nesses municípios, o que se pretende fazer através da contratação de uma equipe a ser composta por educadores. Ainda assim, pelo conjunto da iniciativa do inventariamento dos bens culturais e da socialização dos conhecimentos sobre esses bens, a representação do IPHAN no Pará recebeu menção honrosa no VII Prêmio Somos Patrimônio, promovido em 2008 pela Organización del Convenio Andrés Bello, onde o INRC Marajó figura na categoria Experiência Destacada. (13)

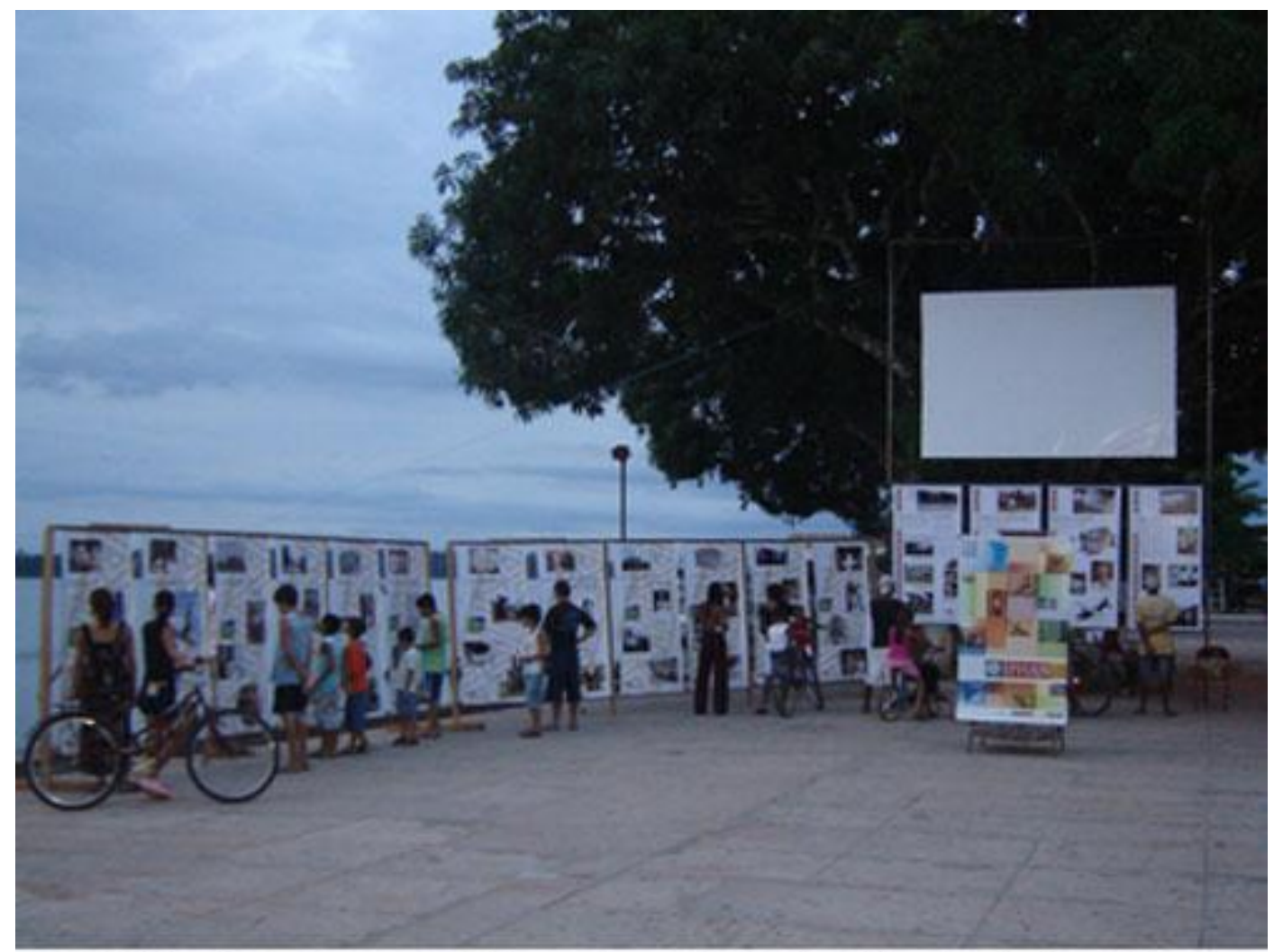

FIGURA 6 - Vista da exposição itinerante na orla de Săo Sebastião da Boa Vista. Na foto pode ser observado, também, o telão montado para a projeção do DVD à populaçăo local. Foto: Giovanni Sarquis, 2007. 


\section{Considerações finais}

Embora a noção de disseminação da informação esteja mais evidente no contexto das práticas biblioteconômicas, arquivísticas, documentárias e museológicas, pessoas jurídicas ou físicas estão envolvidas no dia a dia com alguma forma de divulgação de informações, isso quando a palavra divulgação é tomada como o entendimento mais elementar sobre o que vem a ser a disseminação. Todavia, considerada na perspectiva do Estado, tais práticas carregam consigo um ideal democrático, sobretudo do ponto de vista do dever da publicização dos feitos da Administração Pública, tal como se pôde verificar no caso do IPHAN quanto à realização do INRC Marajó e a consequente dinamização dos conteúdos coletados pela equipe de pesquisa que se converteram em produtos culturais na forma de Inventário, exposições, palestras, DVD e CD-ROM.

De todo modo, há que se buscar os meios para dar maior visibilidade aos inventários como o da llha do Marajó, precipuamente na disseminação dos saberes e das práticas que permitam à sociedade conhecer a diversidade e as particularidades culturais do país. Assim, quiçá a efetivação do Sistema de Bens Culturais Registrados na Internet possa viabilizar a disseminação do volume de informações produzido sobre o patrimônio cultural imaterial no Brasil, o que tornará possível o acesso a esses conteúdos em escala nacional e global. Em especial, contribuindo para a promoção do legado cultural dos segmentos e das comunidades cujas práticas são mal compreendidas, ou na pior das hipóteses, tratadas como produção simbólica e/ou material de menor importância quando analisadas numa perspectiva etnocêntrica. Mas em que pesem as dificuldades técnicas, logísticas, orçamentárias e políticas que permeiam as ações de inventariamento, a experiência do IPHAN no Pará com o INRC Marajó é da maior importância não somente no que diz respeito ao registro e à disseminação das informações coletadas, mas, sobretudo para o fortalecimento das identidades e para a valorização dos conhecimentos e dos saberes tradicionais em tempos de pós-modernidade. 


\section{Notas}

(1) O INRC consiste em uma metodologia sistemática e exaustiva de inventário desenvolvida pela Andrade e Arantes Consultoria e Projetos Culturais, aplicada tanto aos bens culturais de natureza material quanto imaterial. Estrutura-se sobre orientações metodológicas à equipe de pesquisa, bem como de fichas (planilhas) destinadas à coleta de informações sobre celebrações, formas de expressão, ofícios e modos de fazer, edificações e lugares. Essas informações, por sua vez, são armazenadas em bancos de dados mantidos e geridos pelo IPHAN (IPHAN, 2000).

(2) Rubens Ferreira na condição de técnico do IPHAN e Sheila Fonseca na condição de estagiária.

(3) A ampliação do conceito de patrimônio cultural para a dimensão imaterial no Brasil aparece inicialmente na Constituição de 1988 (BRASIL, 2009), o que viabilizou, ainda nos anos de 1990 do século passado, as discussões em torno da necessidade de criação de instrumentos legais e metodologias para a identificação, proteção e salvaguarda dos conhecimentos associados aos modos de fazer, das formas de expressão tradicionais das comunidades, dos espaços destinados aos ritos e às celebrações relevantes para os diferentes grupos formadores da sociedade brasileira e outros aspectos simbólicos da vida humana dotados de significado compartilhados pela coletividade.

(4) A encantaria corresponde a uma dimensão sobrenatural do reino das águas, habitada por seres e entidades do sistema de crença da pajelança.

(5) Faz-se necessário esclarecer pelo menos três sentidos possíveis para o termo registro. O primeiro deles refere-se à atividade técnica de atribuição de um número de identificação a um item documental em um sistema de informação. O segundo diz respeito à fixação da informação em algum suporte, a fim de permitir que ela seja acessada tantas vezes quantas forem possíveis. Assim, o ato de escrever um texto ou realizar uma gravação sonora ou audiovisual são exemplos de registro nesta acepção, e é neste sentido que o INRC Marajó está sendo analisado. Outra dimensão semântica da palavra registro refere-se ao instrumento legal de proteção do patrimônio imaterial instituído pelo Decreto 3.551/2000 (BRASIL, 2006), que se opõe ao termo tombamento, sendo este último empregado na proteção do patrimônio material (igrejas, esculturas, telas, documentos, móveis etc.).

(6) Uma segunda fase de inventariamento foi realizada no início de 2009 em Portel, Gurupá e Bagre, e encontrase atualmente em fase de conclusão.

(7) Cada estrutura na qual se efetua o registro de uma determinada informação, tal como ocorre em uma base de dados bibliográfica, onde se identifica o nome do autor, título, edição, local de publicação, ano etc. (ROWLEY, 2002, p.108).

(8) Até o momento existem 15 bens registrados como patrimônio imaterial do Brasil: (1) Ofício das Paneleiras de Goiabeiras; (2) Arte Kusiwa dos Wajãpi; (3) Círio de Nossa Senhora de Nazaré; (4) Samba de Roda do Recôncavo Baiano; (5) Modo de Fazer Viola-de-Cocho; (6) Ofício das Baianas de Acarajé; (7) Jongo no Sudeste; (8) Cachoeira de lauaretê - Lugar sagrado dos povos indígenas dos Rios Uaupés e Papuri; (9) Feira de Caruaru; (10) Frevo; (11) Tambor de Crioula; (12) Matrizes do Samba no Rio de Janeiro: Partido Alto, Samba de Terreira e Samba-Enredo; (13) Modo artesanal de fazer Queijo de Minas, nas regiões do Serro e das serras da Canastra e 
do Salitre; (14) Roda de Capoeira e Ofício dos Mestres de Capoeira; e (15) modo de fazer Renda Irlandesa produzida em Divina Pastora (SE) (IPHAN, 2009).

(9) Pequena embarcação comum na Amazônia, construída a partir de um único tronco de árvore.

(10) O miniauditório da sede do IPHAN, em Belém, tem capacidade para não mais que 40 pessoas sentadas.

(11) Expressão cultural paraense que combina música e dança, ritmada pelo som de um tambor conhecido como curimbó. Atualmente, o carimbó encontra-se em fase de inventariamento pela representação do IPHAN no Pará.

(12) Informação obtida via e-mail, em 25 ago. 2009.

(13) Informação obtida da base de dados Lattes, precisamente do currículo de Carla Belas e Karla Oliveira, participantes da equipe de pesquisa do INRC Marajó.

\section{Referências bibliográficas}

ALMEIDA, Carlos Cândido de. A Ciência da Informação e a sociedade brasileira: algumas representações de pesquisadores da área. Transinformação, Campinas, v. 18, n. 3, p. 169-190, set./dez., 2006.

ANDRADE, Maria Eugênia Albino; OLIVEIRA, Marlene de. A Ciência da Informação no Brasil. In: OLIVEIRA, Marlene de (Org.). Ciência da Informação e Biblioteconomia: novos conteúdos e espaços de atuação. Belo Horizonte: UFMG, 2005. p. 45-60.

ARRAYA, Elizabeth Roxana Mass; VIDOTTI, Silvana B. Gregório. O papel da Ciência da Informação no desenho antropocêntrico das Tecnologias de Informação e Comunicação. In: CONGRESO DE LA CIBERSOCIEDAD: CRISIS ANALÓGICA, FUTURO DIGITAL, 2009. Anais... [S. I.: s. n.], 2009 . Disponível em:<http://www.cibersociedad.net/congres2009/es/coms/o-papel-da-cincia-da-informasao-nodesenhoantropocntrico-das-tecnologias-de-informasao-e-comunicasao/1115/>. Acesso em: 16 dez.2009.

BRAGA, Gilda Maria. Informação, Ciência da Informação: breves reflexões em três tempos. Ciência da Informação, Brasília, v. 24, n. 1, não paginado, 1995.

BRASIL. Constituição (1988). Constituição Federal do Brasil. São Paulo: Escala, 2009. Atualizada até 2009.

Decreto no 3.551, de 4 de agosto de 2000. Institui o Registro de Bens Culturais de Natureza Imaterial que constituem patrimônio cultural brasileiro, cria o Programa Nacional do Patrimônio Imaterial e dá outras providências. In: IPHAN. Coletânea de leis sobre preservação do patrimônio. Rio de Janeiro: IPHAN, 2006. p. 129-131. (Edições do Patrimônio).

CAPURRO, Rafael; HJORLAND, Birger. O Conceito de informação. Perspectiva em Ciência da Informação, Belo Horizonte, v. 12, n. 1, p. 148-207, jan./abr. 2007. 
CONVENÇÃO para a salvaguarda do patrimônio cultural imaterial, Paris, 17 de outubro de 2003 MISC/2003/CLT/CH/14. In: CURY, Isabele (Org.). Cartas patrimoniais. 3. ed. Rio de Janeiro: IPHAN, 2004. p. 371-390.

DAVENPORT, Thomas H. Ecologia da informação: por que só a tecnologia não basta para o sucesso na era da informação. São Paulo: Futura, 1998.

ECO, Umberto. Como se faz uma tese. 14. ed. São Paulo: Perspectiva, 1996.

FERREIRA, Rubens da Silva. Relatório de viagem a Salvaterra. Belém: IPHAN/Pará, 2007

Relatório de viagem a Muaná. Belém: IPHAN/Pará, 2007.

Relatório de viagem a Ponta de Pedras. Belém: IPHAN/Pará, 2007.

IPHAN. Ação institucional. Brasília, [2009]. DF, Disponível em:<http://portal.iphan.gov.br/portal/montarPaginaSecao.do?id=12138\&retorno=paginalphan $>$. Acesso em: 15 dez. 2009.

IPHAN. Departamento de Identificação e Documentação. Inventário Nacional de Referências Culturais: manual de aplicação. Brasília, DF, 2000.

Bens registrados. Brasília, 2009. Disponível em: $<$ http://portal.iphan.gov.br/portal/montarPaginaSecao.do?id=12456\&retorno=paginalphan $>$. Acesso em: $15 \mathrm{dez}$. 2009.

Inventário Nacional de Referências Culturais: levantamento preliminar ilha do Marajó. Belém: IPHAN, 2006. 2 v.

MAUÉS, Raymundo Heraldo. A ilha encantada: medicina e xamanismo. Belém: UFPA, 1990.

Padres, pajés, santos e festas: catolicismo popular e controle eclesiástico: um estudo antropológico numa área do interior da Amazônia. Belém: Cejup, 1995.

OLIVEIRA, Maria Odaisa Espinheiro. A disseminação da informação na construção do conhecimento e na formação da cidadania. In: CONGRESSO BRASILEIRO DE BIBLIOTECONOMIA E DOCUMENTAÇÃO, 19., 2000. Proceedings... Disponível em: <http://dici.ibict.Br/archive/00000776/01/t/25.pdf>. Acesso em: 2 out. 2009.

PINHEIRO, Lena Vânia Ribeiro; LOUREIRO, José Mauro Matheus. Traçados e limites da Ciência da Informação. Ciência da Informação, Brasília, v. 24, n. 1, 1995. Disponível em: <www.ibict.br/cionline/viewarticle.php?id=576> Acesso em: 12 jan. 2007.

RECOMENDAÇÕES sobre a salvaguarda da cultura tradicional popular, Conferência Geral da UNESCO - 25a Reunião, Paris - 15 de novembro de 1989. In: CURY, Isabele (Org.). Cartas patrimoniais. 3. ed. Rio de Janeiro: IPHAN, 2004. p. 293-301. 
ROWLEY, Jennifer. A biblioteca eletrônica. 2. ed. Brasília, DF: Briquet de Lemos, 2002.

VALLE, Raul Silva Telles do. Direito à informação: marco legal. [S.I: s.n.], 2005.

ZEMAN, Jirí. Significado filosófico da noção de informação. In: ROYAUMONT, Cahiers. O conceito de informação na Ciência contemporânea. Rio de Janeiro: Paz e Terra, 1970. p. 154-168.

\section{Crédito}

* Bacharel em Biblioteconomia.

e-mail: sheilatapajos@yahoo.com.br

** Bacharel em Biblioteconomia, especialista em Biblioteca Universitária, mestre em Planejamento do Desenvolvimento Regional. Docente e Pesquisador da Universidade Federal do Pará (UFPA).

e-mail: rubensf@ufpa.br 